\title{
PEMBELAJARAN IPS BERBASIS KEARIFAN LOKAL SEBAGAI PEMBENTUK PENDIDIKAN KARAKTER DI SEKOLAH
}

\author{
Nurhikmah \\ 1910128120006@mhs.ulm.ac.id \\ Program Studi Pendidikan IPS Fakultas Keguruan dan Ilmu Pendidikan \\ Universitas Lambung Mangkurat \\ Abstrak
}

Seiring berkembangnya zaman, kita semua dituntut untuk mampu untuk menjawab semua tantangan yang ada. Melalui pendidikan, kita kita memiliki kekuatan untuk menjawab tantangan tersebut. Dengan adanya pendidikan berbasis kearifan lokal, yang mana di dalam kearifan lokal terdapat pendidikan karakter didalannya dan sebagai satu diantara sumber nilai moral yang baik. Kearifan lokal terdiri dari nilai-nilai yang dinggap baik oleh suatu masyrakat tertentu yang mereka jadikan sebagai pedoman untuk mengatur pola perilaku di tengah masyarakat. Maka dari itu, pendidik harus mampu merancang pembelajaran yang memuat kearifan lokal yang ada di lingkungan peserta didik. Dari pembelajaran yang mengaitkan dengan kearifan lokal, dapat menciptakan pembelajaran yang bermakna untuk peserta didik.

Kata Kunci: Pendidikan Karakter, Pembelajaran, Kearifan Lokal

\section{PENDAHULUAN}

Saat ini kebaradaan kearifan lokal di tengah-tengah masyarakat mulai terkisis dengan perkembangan teknologi yang semakin cepat. Dengan masuknya budaya modern dapat menyebebkan menghilangnya suatu kerifan lokal, karena masyarakat tidak mampu menyaring budaya yang masuk, padahal kearifan lokal berberan untuk menyaring nilainilai yang mana baik atau buruk yang sesuai dengan karakter bangsa Indonesia. Oleh Karena itu fungsi dan tujuan pendidikan yang telah diatur dalam UU No. 20 tahun 2003 tentang sistem pendidikan Nasional fungsi pendidikan temuat dalam pasal 3 yang menjelaskan bahawa "Pendidikan nasional berfungsi mengembangkan kemampuan dan membentuk watak serta peradapan bangsa yang bermatabat dalam rangka mencerdaskan kehidupan bangsa,bertujuan untuk berkembangnya potensi peserta didik agar menjadi manusia yang beriman dan bertakwa kepada Tuhan Yang Maha Esa,Berakhlak mulia,sehat,berilmu,cakap,kreatif,mandiri,dan menjadi warga negara yang demokratis serta bertanggung jawab."

Dalam pendidikan terjadi proses tranfer ilmu pengetahuan, menjaga dan mengembangkan nilai, budaya, tradisi, norma dan lain sebagainya. (Sujana, 2019). Pada era globalisasi sekarang terjadi perubahan yang sangat cepat dalam berbagai bidang kehidupan, pengaruhnya pun juga berdampak pada memudarnya nilai budaya yang ada di dalam masyarakat. Oleh karena itu untuk tetap menjaga nilai-nilai budaya lokal agar tidak tergeser diperlukan pembelajaran yang berbasis kearifan lokal yang sesuai dengan prinsip pendidikan.

Pendidikan karakter yang terdapat pada kearifan lokal yang diajarkan guru kepada peserta didik dapat membangun karakter generasi bangsa dan membangun jatidiri bangsa 
Indonesia. Oleh karena itu, penulis disini akan mendeskripsikan pembelajaran IPS berbasis kearifan lokal sebagai pembentuk pendidikan karakter di sekolah.

\section{PEMBAHASAN}

Pendidikan diartikan sebagai perkembanganintek=lektual dimana peserta didik memperoleh keterampilan dan kebajikan parenial (parennial truth). Teapi pendidikan juga diartikan sebagai proses fundamental dimana perilaku dibentuk dan dipertahankan agar bermanfaat bagi individu dan orang lain di masa yang akan datang (Anwar, 2003; Mutiani, 2018). Sekarang pendidikan mengamali tantangan di era globalisasi, dimana kita dihadapkan dengan perkembangan zman yang yang dapat menggerus budaya lokal atau kearifan lokal. Pendidikan dan pemahaman terhadap nudaya lokal menjadikan sebuah strategi untuk mengimplementasiakan nilai-nilai luhur budaya di daerah masing-masing (Mutiani, 2018).

Kebudayaan merupakan bentuk keseluruhan dari pengetahuan manusia yang mereka gunakan untuk memahami dan menginterpretasikan lingkungan dan pengalamannya (Syam, 2007; Mutiani, 2018). Dalam kebudayaan terdapat nilai dimana nilai tersebut mendorong masyarakat untuk bereaksi pada lingkungan sekitarnya. Seperti yang dinyatakan oleh Koenjaraningrat dalam Mutiani (2018) mengatakan bahwa Nilai budaya merupakan suatu rangkaian dari pemikiran masyarakat, mengenai hal yang dianggap penting dan berharga.

Menurut Mutiani (2018) sikap individu terhadap nilai budaya ditentukan oleh 3 unsur yang meliputi jiwa, norma-norma dan konsep nilai budaya. Artinya nilai budaya pada kondisi tertentu menjadi pedoman terhadap norma sosial atau hukum yang ada di masyarakat.

Pembelajaran berdasarkan nilai-nilai budaya lokal berarti mengaplikasikan prinsip kebangsaan dalam membangun generasi bangsa dalam artian membentuk karakter bangsa melalui pendidikan karakter. Karakter diartikan sebagai cara berfikir dan berperilaku yang khas tiap individu, baik dalam lingkup keluarga, masyarakat, bangsa, dan negara. Individu yang berkarakter baik adalah individu yang dapat membuat keputusan dan siap mempertanggungjawabkan setiap akibat dari keputusannya. Karakter dapat dianggap sebagai nilai-nilai perilaku manusia yang berhubungan dengan Tuhan Yang Maha Esa, diri sendiri, sesama manusia, lingkungan, dan kebangsaan yang terwujud dalam pikiran, sikap, perasaan, perkataan, dan perbuatan berdasarkan norma-norma agama, hukum, tata karma, budaya, adat itiadat, dan estetika (Samani \& Hariyanto, 2013; Ramdhani; 2017).

Pendidikan karakter bertujuan untuk meningkatkan mutu pendidikan dan hasil pendidikan, melalui pendidikan karakter peserta didik diharapkan dapat menginternalisasikan nilai-nilai karakter (Mulyasa, 2013; Ramdhani;2017). Karakter yang berkualitas perlu dibentuk sejak usia dini. Oleh karena itu penanaman pendidik karakter sedini mungkin kepada peserta didik merupakan kunci membangun karakter bangsa. (Syaharudin, 2016). 
Pendidikan karakter tidak hanya mangajarkan mana yang baik dan buruk tetapi juga berusaha menanamkan kebisaaan baik agar peserta didik berperilaku sesuai dengan nilai-nilai yang ada di lingkungannya. Pada dasarnya pendidikan karakter membantu mempersiapkan peserta didik agar dapat bertindak sesuai dengan norma dan moral yang berlaku dalam masyarakat.

Melalui pendidikan karakter dengan mengantikan pembelajaran dengan nilai kearifan lokal, maka kana memperkuat jati diri bangsa Indonesia dan peserta didik bangga dengan budaya lokal yang mereka miliki. Pada proses pembelajaran yang berbasis kearifan lokal pastinya tidak akan selalu berjalan mulus. Adapun faktor-faktor yang dapat menghambat implemntasi pendidikan karakter berbasis kearifan lokal seperti tidak tersedia sumber belajar seperti buku yang memuat budaya kearifan lokal terkait sehingga dapat menghambat transfer budaya dari pendidik kepada pesert didik.

Pembelajaran IPS merupakan pembelajaran yang mengintegrasikan konsep terpilih dari berbagai ilmu-ilmu sosial dan humaniora yang bertujuan agar peserta didik mampu memahami konsep secara holistik dan berlangsung secara optimal. Pengetahuan Sosial mempunyai peran membantu dalam menyiapkan warga negara demokratis dengan penanaman nilai-nilai kebangsaan dan kewarganegaraan didukung oleh penguasaan disiplin ilmu-ilmu sosial. Tujuan dari penelitian ini agar para peserta didik dapat memiliki pengetahuan dan wawasan tentang konsep-konsep dasar ilmu sosial dan humaniora, memiliki kepekaan dan kesadaran terhadap masalah sosial di lingkungannya, serta memiliki keterampilan mengkaji dan memecahkan masalah-masalah sosial tersebut. (Mutiani, 2019)

Adapun fungsi dan peranan pembelajaran IPS yang dijelaskan oleh Martorella, Beal, \& Bolick, 2005; dalam Mutiani, 2019 menjelaskan bahwa fungsi pembelajaran IPS sebaga berikut;

a. Memberi bekal pengetahuan dasar, baik untuk melanjutkan ke jenjang pendidikan lebih tinggi maupun diterapkan dalam kehidupan sehari hari.

b. Mengembangkan keterampilan dalam mengembangkan konsep IPS.

c. Menanamkan sikap ilmiah dan melatih peserta didik menggunakan metode ilmiah untuk memecahkan masalah yang dihadapi.

d. Menyadarkan peserta didik berkenaan kekuatan alam dan segala keindahannya sehingga peserta didik terdorong untuk mencintai dan mengagungkan penciptanya. e. Memupuk daya kreatif dan inovatif siswa.

f. Membantu peserta didik memahami gagasan atau informasi baru dalam bidang Ilmu Pengetahuan dan Teknologi (IPTEK).

g. Memupuk diri serta mengembangkan minat siswa terhadap IPS.

Menurut Prasetyo (2013: 3) kearifan lokal berasal dari dua istilah yakni kearifan (wisdom) dan lokal (local). Secara terminologi, istilah kearifan lokal mengandung arti kearifan setempat yang dimaknai sebagai sebuah ide lokal yang bersifat bijaksana, yang bernilai dan dijadikan tuntunan bagi masyarakat. Sedangkan jika mengkaji pada sudut pandang ilmu antropologi, istilah kearifan lokal ini mengandung makna sebagai sebuah pengetahuan setempat yaitu kemampuan masyarakat setempat 
untuk melakukan proses seleksi terhadap masuknya kebudayaan lain yang disesuaikan dengan budaya lokal yang merupakan penciri atau identitas kebudayaan.

Pembelajaran IPS berbasis kearifan lokal dimana pembelajaran IPS mengintegrasikan nilai-nilai yang ada pada kearifan lokal pada proses pembelajaran. Nilai-nilai kearifan lokal yang ada di masyarakat merupakan bagian dari lingkungan peserta didik. Seperti dihadapkan permasalahan sosial yang ada di sekitarnya, bagaimana permasalahan tersebut bisa muncul dan bagaimana cara peserta didik menyikapi permasalahan tersebut.

Pembelajaran berbasis kearifan lokal dapat meningkatkan kompetensi peserta didik karena menyajikan materi yang kontekstual dan berada di kehidupan sehari-hari peserta didik. Kearifan lokal penting diketahui oleh peserta didik agar dapat melestarikan budaya lokal sehingga tidak terkikis oleh globalisasi. Bahan materi pembelajaran yang berbasis kearifan lokal seperti nilai, norma, adat istiadat yang terjaga di masyarakat dapat dijadikan sumber belajar.

\section{SIMPULAN}

Nilai yang terkandung dalam sebuah kearifan lokal dapat dijadikan sebagai satu diantaa sumber belajar IPS, dengan harapan dapat memberikan pengalaman belajar yang konkrit kepada peserta didik dan pembelajaran akan bermakna. Pada kearifan lokal terkadung pendidikan karaker, pendidikan karakter dapat membentuk perilaku individu agar berperilaku sesuai dengan norma yang berlaku di masyarakat.

\section{DAFTAR PUSTAKA}

Sujana, I. W. C. (2019). Fungsi dan tujuan pendidikan Indonesia. Adi Widya: Jurnal Pendidikan Dasar, 4(1), 29-39.

Mutiani, M. (2018). Literasi Budaya Lokal Sebagai Wahana Edukasi Di Era Milenial.

Ramdhani, M. A. (2017). Lingkungan pendidikan dalam implementasi pendidikan karakter. Jurnal Pendidikan UNIGA, 8(1), 28-37.

Syaharuddin, S., Pasani, C. F., \& Mariani, N. (2016). Implementasi Pendidikan Karakter Berbasis Kearifan Lokal Bakumpai di SDN Batik Kabupaten Barito Kuala.

Mutiani, M., Subiyakto, B., Jumriani, J., Aslamiah, A., \& Afrina, A. (2019). Laporan Penelitian: Relevansi Modal Sosial Dalam Pembelajaran IPS (Studi Kasus Dalam Sistem Zonasi Di Smp Negeri Kota Banjarmasin).

Setiawan, I., \& Mulyati, S. (2020). PEMBELAJARAN IPS BERBASIS KEARIFAN LOKAL. Jurnal Ilmiah Pendidikan Dasar, 7(2), 121-133.

Subiyakto, B., \& Mutiani, M. (2019). Internalisasi nilai pendidikan melalui aktivitas masyarakat sebagai sumber belajar ilmu pengetahuan sosial. Khazanah: Jurnal Studi Islam dan Humaniora, 17(1), 137-166. 